\title{
LINUX SEBAGAI ALTERNATIF PENDIDIKAN KOMPUTER
}

\begin{abstract}
Abstrak
Computer education is one of necessaries that very elementer. It caused by curriculum of national education demands that apply technological information on intra curricular lesson. Beside that, the competence in global era that demand the existence of simplicity on each job that done so that needed the existence of computer system completely. However, in harmony the demand, the expensive of an operating systems is one of obstacle in studying computer to more creative.

Linux is one of the alternative computer education that can overcome the problem. Linux capacity can be used and developed by everyone is main pole to develop computer education in Indonesia. Beside that, Linux starts from an operating system UNIX, has many specialty for example operating system Linux has a characteristic that is open source, the similarity between Linux and Windows, make the user can operate without studying for along time.

Hopefully by the existence this writing task can change the thinking way of Indonesian about Linux and to study computer is not an obligation ton expensive with an operating system that has a license.
\end{abstract}

\section{Keywords : education, Linux, computer}

\begin{abstract}
Abstrak
Pendidikan komputer adalah salah satu perlu itu sangat elementer. Ini disebabkan oleh kurikulum dari permintaan Pendidikan nasional yang berlaku keterangan teknologi pada pelajaran intra curricular. Di sebelah tersebut, kemampuan pada era global permintaan itu keberadaan dari kesederhanaan pada masing-masing pekerjaan yang lakukan bahwa dibutuhkan keberadaan dari mesin komputer sama sekali. Bagaimanapun, dalam keselarasan permintaan, mahal dari satu sistem operasi adalah salah satu rintangan di komputer belajar untuk lebih kreatif.

Linux adalah salah satu komputer alternatif Pendidikan itu dapat mengatasi masalah. Kapasitas Linux dapat terpakai dan dikembangkan oleh semua orang adalah kutub utama untuk mengembangkan Pendidikan komputer di Indonesia. Di sebelah tersebut, Linux mulai dari satu sistem operasi tidak IX., punya banyak keahlian khusus antara lain sistem operasi Linux Yang punya satu karakteristik yang sumber buka, persamaan di antara Linux dan Windows, buat pengguna dapat mengoperasikan tanpa belajar untuk sepanjang waktu.
\end{abstract}

